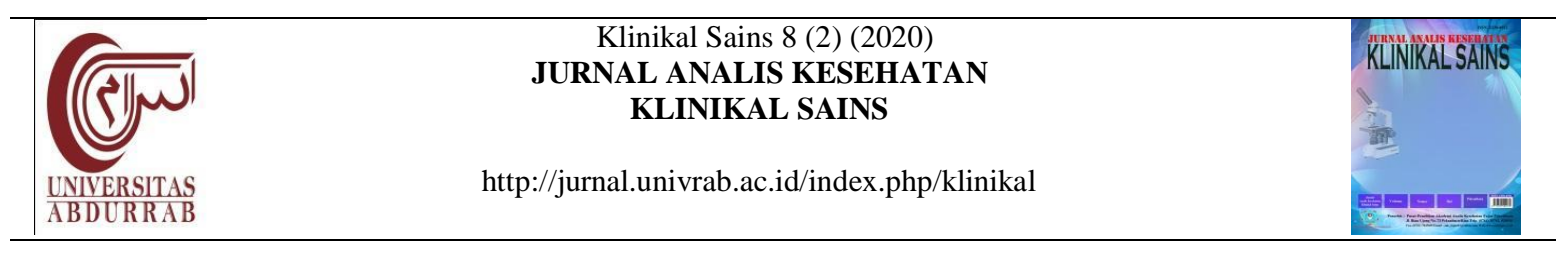

\title{
REVIEW : PATOGENESIS DAN DIAGNOSA LABORATORIUM DEMAM TIFOID
}

\author{
Dian Nurmansyah $^{1}$, Normaidah ${ }^{2}$ \\ ${ }^{1}$ Program Studi D-III Teknologi Laboratorium Medik, Akademi Analis Kesehatan Borneo Lestari, \\ Banjarbaru, Kalimantan Selatan \\ ${ }^{2}$ Program Studi Farmasi, Fakultas MIPA, Universitas Lambung Mangkurat, \\ Banjarbaru, Kalimantan Selatan \\ Jalan Kelapa Sawit 8 Bumi Berkat No.1, Banjarbaru, Kalimantan Selatan \\ dian@aakborneolestari.ac.id
}

\begin{abstract}
Info Artikel Abstrak

Sejarah Artikel:

Demam tifoid disebabkan oleh Salmonella typhi diketahui telah menyebabkan kematian lebih dari 600.000 jiwa di seluruh dunia. Pemahaman terhadap patogenesis dan pemeriksaan laboratorium yang tepat sangat berpengaruh terhadap keberhasilan

Diterima Juli 2020

Disetujui Agustus 2020

Dipublikasikan terapi. Literature review ini bertujuan untuk mengumpulkan pustaka yang berkaitan dengan patogenesis dan pemeriksaan laboratorium pada demam tifoid. Metode literature review ini menggunakan model Sistematic Literature Review (SLR) Desember 2020 berdasarkan patogenesis dan pemeriksaan laboratorium. Infeksi Salmonella typhi dimulai dengan masuknya bakteri melalui saluran cerna dan dapat berlangsung hingga 3 minggu. Pemeriksaan laboratorium demam tifoid meliputi kultur bakteri, pemeriksaan serologi, pemeriksaan molekuler, dan pemeriksaan penunjang lainnya. Kultur bakteri merupakan gold standard yang memiliki sensitivitas hingga $80 \%$

Keywords: pada darah. Pemeriksaan serologi dapat dilakukan seperti tes Widal, ELISA, SDSPAGE blotting, RDT atau POCT menggunakan sampel darah vena, darah kapiler, bahkan serum, serta typhidot, dan Tubex TF. Pemeriksaan penunjang lain dapat

Demam Tifoid; Patogenesis demam tifoid, Salmonella typhi ditandai dengan leukositosis dan eosinopenia. Pemeriksaan kimia darah juga didapatkan peningkatan AST dan ALT 2-3 kali lipat dari nilai normal.
\end{abstract}

Kata Kunci: Demam tifoid, Patogenesis Demam tifoid, Salmonella typhi,

\section{Abstract}

Typhoid fever caused by the pathogen bacteria named Salmonella typhi is known to have caused the death of more than 600,000 people worldwide. Understanding the patogenesis and proper laboratory examination is very influential on the success of therapy. This literature review aims to collect literature related to patogenesis and laboratory examination in typhoid fever. This literature review method uses the Systematic Literature Review (SLR) model based on patogenesis and laboratory examinations. Salmonella typhi infection begins with the entry of bacteria through the gastrointestine tract and can last up to 3 weeks. Laboratory tests for typhoid fever are bacterial culture, serological examination, molecular examination, and other investigations. Bacterial culture is a gold standard that has a sensitivity of up to $80 \%$ in blood. Serological tests can be performed such as Widal, ELISA, SDSPAGE blotting, RDT or POCT tests using venous blood, capillary blood, even 
serum, and typhidot, and Tubex TF. Other investigations can be characterized by leukocytosis and eosinopenia. Blood chemistry tests also found an increase of AST and ALT 2-3 times the normal value.

(C) 2020 Universitas Abdurrab

\footnotetext{
Alamat korespondensi: Jl. Kelapa Sawit 8 Bumi Berkat, ISSN 2338-4921 Banjarbaru

E-mail: dian@aakborneolestari.ac.id
}

\section{PENDAHULUAN}

Demam tifoid adalah penyakit infeksi yang disebabkan oleh bakteri Salmonella typhi. Demam tifoid termasuk penyakit endemis di negara berkembang, salah satunya di Indonesia (Sidabutar \& Satari, 2010). Angka kesakitan demam tifoid dirilis oleh WHO berjumlah 21 juta kasus di seluruh dunia dengan angka kematian > 600.000 jiwa (Andualem, et al., 2014). Suatu proyek Global Burden of Disease (GBD 2010) memperkirakan demam tifoid dan paratifoid telah terjadi sebanyak 12,2 juta jumlah kesakitan dan 190.200 kematian. Selain itu, The International Vaccine Institute juga memperkirakan sebanyak 11.9 juta angka kesakitan dan 129.000 kematian terjadi di negara dengan pendapatan rendah sampai menengah (Lozano, et al., 2010; Mogasale, et al., 2014). Seseorang yang telah terinfeksi Salmonella thypi dapat menularkan dan menyebarkan bakteri tersebut kepada orang lain pada fase awal sampai dengan periode convalenscene (periode penyembuhan) (Nelwan, 2012). Pemahaman terhadap patogenesis atau perjalanan penyakit sangat berpengaruh terhadap keberhasilan terapi. Selain pemahaman terhadap patgenesis, pemeriksaan laboratorium yang tepat juga menjadi faktor pendukung keberhasilan penyembuhan pasien dengan demam tifoid. Literature review ini bertujuan untuk mengumpulkan pustaka yang berkaitan dengan patogenesis dan pemeriksaan laboratorium pada demam tifoid.

\section{METODE PENELITIAN}

Metode literature review ini menggunakan model Sistematic Literature Review (SLR) dengan menjelaskan secara terstruktur patogenesis demam tifoid dan penjelasan pemeriksaan laboratorium yang dikerjakan dalam penegakan diagnosa demam tifoid.

1. Kultur Bakteri Salmonella typhi

Mengembangbiakan bakteri Salmonella typhi dapat dilakukan dengan menggunakan media Mac Conkey (Sheikh, 2011) . Media lain yang dapat digunakan adalah EMB (eosin methylene blue), deteksi bakteri Salmonella typhi juga dapat menggunakan medium Bismuth Sulfit Agar. Media yang lebih spesifik seperti Salmonella Shigella 
Agar (SSA). Media kultur yang direkomendasikan adalah media empedu (Gall) dari sapi karena dapat meningkatkan sensitivitas pemeriksaan karena hanya bakteri Salmonella typhi dan Salmonella paratyphi yang dapat tumbuh di media ini. Pada media SSA hasil positif Salmonella typhi ditandai dengan terbentuknya koloni hitam (black jet) karena produksi $\mathrm{H}_{2} \mathrm{~S}$ (Sucipta, 2015).

2. Pemeriksaan Serologi Pemeriksaan serologi yang dapat digunakan adalah Widal Test, Tubex TF, ELISA, hingga SDS-PAGE Blotting. Pemeriksaan serologi pada umum nya adalah deteksi Antibodi(Ab) atau Antigen (Ag) bakteri Salmonella typhi. Reagen kit widal telah banyak diproduksi oleh vendor/perusahaan sehingga dapat menjadi pemeriksaan rutin yang dapat dikerjakan di laboratorium., namun yang perlu diperhatikan adalah perlu diperhatikan kualitas pengerjaan, karena belum ada kesepakatan nilai standar aglutinasi (cut-off point) (Choerunnisa \& Basuki, 2014; Septiawan \& S Herawati, 2013)

Pada pemeriksaan Tubex TF menggunakan kit test Tubex. Test ini menggunakan pemisahan partikel-partikel untuk mendeteksi antibody IgM dari serum pada antigen $\mathrm{O}$ 9 LPS dari bakteri. Spesimen yang digunakan adalah serum atau plasma heparin (Marleni, et al., 2014)

\section{Pemeriksaan Molekuler}

Pemeriksaan berbasis molekuler dapat dilakukan dengan amplifikasi beberapa gene spesifik yang telah diketahui dan diakses melalui Gene Bank di NCBI (National Center for Biotechnology Information, https://www.ncbi.nlm.nih.gov). Genome lengkap dari Salmonella typhi telah dimasukan kedalam basis data dan dapat dipergunakan sesuai dengan gen target. Beberapa gene yang dapat dijadikan target identifikasi seperti 16sRNA, viaB, hiLa dan Flic dari bakteri Salmonella typhi dapat digunakan sebagai primer identifikasi bakteri Salmonella typhi (Liu, et al., 2017)

4. Pemeriksaan Penunjang Lain

Pemeriksaan hematologis dilakukan secara rutin menggunakan Hematology Analyze, sampel terbaik yang digunakan adalah Plasma EDTA dari darah vena. Pemeriksaan penunjang pengukuran AST dan ALT dapat dilakukan menggunakan metode kinetic enzymatic berdasarkan kesepakatan IFCC (International Federation of Clicical Chemistry and Laboratory Medicine) menggunakan sampel serum pada panjang gelombang 340 nanometer (Waddington, et al., 2014; Lestari, et al., 2019)

\section{HASIL DAN PEMBAHASAN}




\section{A. Patogenesis Demam Tifoid}

Dosis infeksi dari bakteri Salmonella typhi hingga dapat menyebabkan penyakit demam tifoid berkisar antara 1000 sampai dengan 1.000 .000 organisme. Demam tifoid yang disebabkan oleh Salmonella typhi ditularkan melalui makanan atau minuman yang tercemar dengan feses manusia yang mengandung bakteri Salmonella typhi. Bakteri yang telah melewati lambung akan menembus mukosa epitel usus dan selanjutnya berkembang biak di dalam makrofag. Bakteri yang telah berkembang biak di dalam makrofag, masuk ke dalam kelenjar getah bening mesenterium, memasuki peredaran darah sehingga terjadi bakterimia pertama yang asimtomatis. Bakteri dalam peredaran darah masuk ke dalam organ - organ terumata hepar dan sumsum tulang, selanjutnya pelepasan bakteri dan endotoksin ke peredaran darah sehingga menyebabkan bakterimia kedua Bakteri yang berada di hepar akan masuk kembali ke dalam usus kecil, sehingga terjadi infeksi seperti semula dan sebagian bakteri akan dikeluarkan bersamaan dengan keluarnya tinja. Waktu inkubasi Salmonella typhi adalah 12 jam sampai dengan 36 jam. Gejala yang timbul pada masa inkubasi dapat berupa demam, sakit pada bagian perut dan dapat terjadi diare (Tortora, et al., 2013)

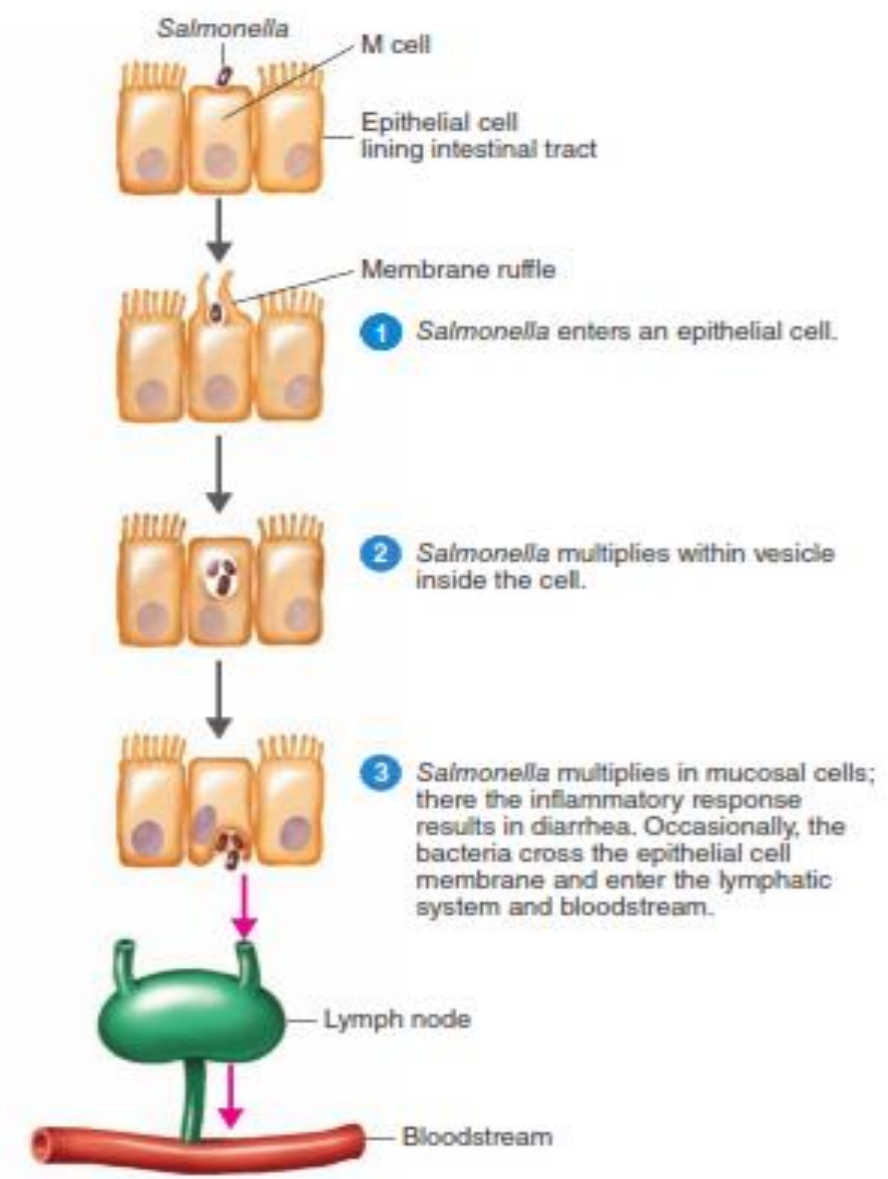




\section{Gambar 1.}

Mekanisme terjadi bakterimia oleh Salmonella typhi (Tortora, et al., 2013)

Secara molekuler patogenesis infeksi Salmonella typhi dimulai ketika bakteri dapat bertahan dari asam lambung dan mencapai ke usus halus. Di usus halus, bakteri akan menembus sel epitel usus untuk kemduian mencapai sel M, kemudian akan memasuki peyer's patch. Setelah kontak dengan sel M, infeksi bakteri akan semakin cepat dan akan mencapai Antigen Precenting Cells (APCs), dimana sebagian akan difagositosis dan dinetralisasi. Fagositosis terhadap bakteri diatur secara tersendiri yang kemudian menjadi lesi patologis di sekitar jaringan normal. Pembentukan lesi adalah proses dinamis yang memerlukan kehadiran molekul adesi seperti ICAM1 (inter-celular adhesion molecul 1), VCAM-1 (Vascular Cell Adhesion Molecul 1) dan adanya keseimbangan peran dari beberapa sitokin seperti TNF- $\alpha$ IL-12, IL-18, IL-14, IL-15 dan interferon (IFN)y. Kegagalan dalam pembentukan lesi patologis akan mengakibatkan terjadinya pertumbuhan abnormal dan penyebaran bakteri di dalam jaringan yang diinfeksi. Beberapa bakteri akan mampu melewati dan akan mencapai folikel limfoid, akan dibentuk oleh sel mononuklear yaitu sel T limfosit, yang akan berfungsi sama baiknya dengan Dendritic Cells (DC). DC akan mempresentasikan bakteri pada sel-sel imun yang akan memicu aktivasi limfosit $\mathrm{T}$ dan limfosit B (Kaur \& Jain, 2012)

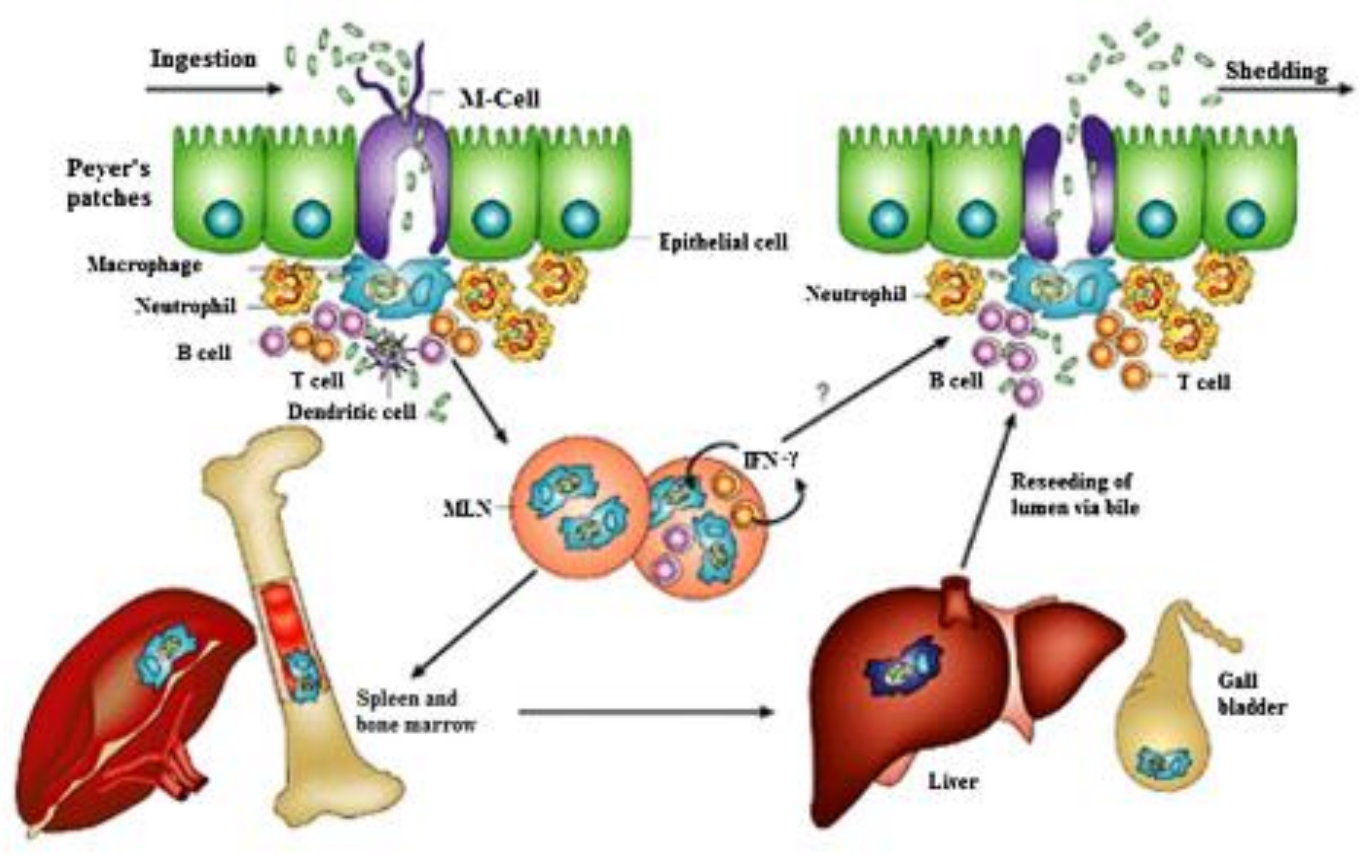

Gambar 2 
Mekanisme infeksi Salmonella typhi secara molekuler (Kaur \& Jain, 2012)

Limfosit $\mathrm{T}$ dan limfosit $\mathrm{B}$ keluar menuju limpho nodus dan akan mencapai hati dan limpa melalui sistem retikuloendotelial. Di dalam organ ini bakteri akan dibunuh dengan mekanisme fagositosis melalui sistem makrofag. Salmonella typhi mampu untuk bertahan dan bermultiplikasi di dalam sel fagositosis mononukleus dalam keadaan apapun (House, et al., 2001). Pada awal mula infeksi, berdasarkan jumlah bakteri, faktor virulensi dari bakteri, dan respon imun dari inang, bakteri akan dilepaskan dari intraseluler menuju ke aliran darah. Fase bakterimia dari penyakit demam tifoid akan ditandai dengan menyebarnya bakteri Salmonella typhi ke berbagai organ seperti hepar, limpa, sumsum tulang, gall bladder, dan Peyer's patch di terminal ileum. Di hepar, Salmonella typhi akan merangsang aktivasi sel Kupffer. Sel Kupffer memiliki sifat mikrobisidal dan akan menetralisir bakteri melalui oksidasi radikal bebas seperti nitric oxide yang akan aktif dalam $\mathrm{pH}$ asam. Bakteri yang mampu bertahan akan menginvasi hepatosit dan menyebabkan kematian sel melalui mekanisme apoptosis (Kaur \& Jain, 2012)

Dalam jangka waktu 1 sampai 3 minggu bakteri akan bereplikasi di hati, limpa, dan sistem retikuloendotelial. Sel yang terinfeksi akan mengalami kerusakan dan menyebabkan bakteri berpindah ke dalam kantung empedu dan menjadi infeksi sekunder pada usus halus pada ileum. Pada fase terjadi kasus infeksi berat, invasi pada mukosa menyebabkan epitel-epitel sel memproduksi dan melepaskan beberapa sitokin proinflamatori termasuk IL-1, IL-6, IL-8. TNF- $\beta$, INF, GM-CSF (Singh, 2001).

Pada organ hepar, Salmonella typhi akan merangsang adanya proliferasi sel-sel radang. Sarang radang yang interlobular disebabkan oleh endotoksin Salmonella typhi yang secara mikroskopis akan terlihat adanya sel-sel epiloid berinti besar, pelebaran sinusoid, peradangan vena sentralis, dan nekrosis pada hepatosit.

Terjadinya nekrosis pada sel-sel hepar ditandai dengan matinya sel sehingga hepar tidak dapat melakukan fungsinya dengan baik. Kemampuan hepar untuk melakukan regenerasi merupakan suatu proses yang sangat penting agar hati dapat pulih dari kerusakan yang ditimbulkan oleh proses infeksi bakteri (Muchtarommah, 2014).

B. Pemeriksaan Laboratorium Demam Tifoid Penegakan diagnosa demam tifoid sangat berkaitan dengan pemahaman patogenesis infeksi Salmonella typhi pada keadaan akut, kronis, dan fase penyembuhan. Pemeriksaan laboratorium yang dipilih harus disesuaikan. Pemeriksaan laboratorium untuk diagnosa demam tifoid dibagi menjadi pemeriksaan baku emas (gold standard) dan pemeriksaan pendukung. 


\section{Kultur Bakteri}

Ketika berhadapan dengan infeksi mikroorganisme, maka pemeriksaan kultur selalau dijadikan sebagai gold standar. Pemeriksaan kutltur dapat mendeteksi keberadaan mikroba dengan baik, memiliki sensitivitas dan spesifisitas yang baik, dapat membedakan mikroba penyebab demam tifoid atau demam enterik yang sama-sama disebabkan oleh mikroba genus Salmonella (Baker, et al., 2010). Bakteri hasil kultur dapat dijadikan isolat untuk keperluan lain seperti tes resistensi terhadap antibiotik untuk penentuan resistensi antibiotik bakteri isolat, karakterisasi genetik dari bakteri dengan teknik molekuler, dan studi epidemiologi (Crump, et al., 2015). Sampel yang digunakan untuk kultur menggunakan darah dan akan memberikan sensitivitas hingga $80 \%$ pada minggu pertama sampai minggu ke 3 infeksi (Gordon, et al., 2010). Beberapa penelitian menyatakan bahwa hasil kultur dengan sampel sumsum tulang menyajikan hasil lebih baik, terutama untuk keperluan diagnosa kuantitatif, namun pemeriksaan menggunakan sumsum tulang jarang dilakukan karena kesulitan pengambilan sampel sumsum tulang dan rasa tidak nyaman pada pasien (Crump, et al., 2015). Salmonella juga dapat ditemukan pada feses pasien. Sebanyak $30 \%$ pasien dengan demam tifoid positif dapat mensekresikan bakteri di fesesnya sampai dengan 3 bulan fase penyembuhan dan $1 \%$ pada sampel urinnya, terutama pada pasien yang tidak medapat terapi dengan benar. Isolasi Salmonella sp. di laboratorium harus memperhatikan biosafety dan biosecurity di laboratorium, penggunaan laboratorium terstandar mutlak diperlukan untuk sensitivitas dan spesifisitas yang baik (Andualem, et al., 2014)

2. Pemeriksaan Serologi

Pemeriksaan serologi pada infeksi digunakan sebagai pemeriksaan penunjang pada diagnosa demam tifoid. Walaupun bukan gold standar, namun pemeriksaan ini memiliki nilai sensitivitas dan spesifisitas yang baik. Pemeriksaan yang sering dan masih digunakan adalah tes Widal. Prinsip tes Widal adalah mengukur antibodi terhadap antigen Salmonella typhi $\mathrm{O}$ dan H (Ley, et al., 2010). Pemeriksaan Widal dapat menentukan apakah infeksi akut atau kronis dengan peningkatan titer antibodi terhadap antigen $\mathrm{O}$ dan $\mathrm{H}$, namun masih memerlukan pemeriksaan lain sebagai penentu diagnosa demam tifoid. ELISA telah digunakan sebagai salah satu pemeriksaan serologi pada infeksi demam tifoid, ELISA mengukur respon antibodi terhadap antigen Vi, LPS, dan OMP bakteri Salmonella typhi (Pulickal, et al., 2009). Pemeriksaan ELISA dengan mendeteksi antigen LPS dan Vi dinilai lebih sensitif dibandingkan dengan uji Widal namun spesifisitas pemeriksaan ini masih 
perlu didukung dengan pemeriksaan yang lain. Pemeriksaan SDS-PAGE blotting yang mengukur antibodi serum terhadap LPS dan antigen flagellar dari Salmonella typhi dan paratyphi dapat dijadikan pilihan lain untuk deteksi serologis demam tifoid (Chart, et al., 2007; Crump, et al., 2015). Pemeriksaan menggunakan RDT (rapid diagnostic test) atau POCT (point of care test) juga telah digunakan secara luas. Pemeriksaan POCT mempunyai metode yang berbeda-beda, beberapa pemeriksaan didesain untuk menggunakan sampel darah vena, darah kapiler, bahkan serum. Mendeteksi IgM dan IgG pada pasien untuk menentukan infeksi akut/kronis pada pasien (Crump, et al., 2015). Typhidot mendeteksi IgM dan IgG spesifik terhadap antigen OMP S. serovar typhi dengan nilai sensitifitas antara $65 \%$ - 93\% (Siba, et al., 2012; Tarupiwa, et al., 2015). Tubex TF juga merupakan pemeriksaan yang mulai digunakan seara luas dengan mendeteksi antibodi terhadap antigen LPS dari Salmonella typhi secara semi-kuantitatif. Nilai sensitivitas pemeriksaan ini adalah 56\% - 100\% dengan spesifisitas 58\% - 100\%, namun Tubex TF belum mampu mendeteksi infeksi yang disebabkan oleh $S$. paratyphi (Tam, et al., 2008; Moore, et al., 2014). Pemeriksaan demam tifoid dengan metode serologis merupakan cara cepat dalam menentukan infeksi Salmonella typhi pada pasien dengan tetap memperhatikan berbagai parameter lain dalam darah.

\section{Pemeriksaan Molekuler}

Amplifikasi asam nukleat dari isolasi bakteri Salmonella typhi menjadi pemeriksaan dengan nilai sensitivitas yang sangat baik, yakni mencapai 90\% (Kumar, et al., 2010). Beberapa gen yang dapat dijadikan target amplifiaksi menggunakan PCR adalah gen Hd-Flagellin Flic-D, gen viaB dari kapsul, tyvelose epimerase gene (tyv), gen 16sRNA, gen hilA, dan beberapa gen lain yang spesifik (Kumar, et al., 2010). Nilai sensitivitas PCR dari hasil kultur darah adalah 90\%, walaupun dalam beberapa laporan penelitian lain didapatkan nilai sensitivitas lebih rendah (Nga, et al., 2010). Metode PCR yang menggunakan sampel sumsum tulang memiliki nilai sensitivitas lebih baik (100\%) dan hasil positif juga dilaporkan bisa ditemui pada sampel urin (Nga, et al., 2010; Kumar, et al., 2012). Pemeriksaan laboratorium PCR digunakan dalam skala kecil penelitian dan belum dapat dijadikan pemeriksaan rutin di laboratorium klinik karena tidak semua laboratorium terfasilitasi PCR.

4. Pemeriksaan Penunjang Lain 
Pada beberapa penelitian dilaporkan bahwa kebanyakan penderita demam tifoid mengalami keadaan leukositosis dan eosinopenia. Walaupun tidak spesifik sebagai penanda adanya infeksi Salmonella typhi, namun pmeriksaan penunjang dapat dijadikan sebagai parameter pendukung penentuan diagnosa (Waddington, et al., 2014). Pemeriksaan kimia darah juga didapati adanya peningkatan AST dan ALT hingga 2 - 3 kali lipat nilai normal (Parry, et al., 2002).

\section{SIMPULAN}

Berdasarkan hasil literature review dapat disimpulkan bahwa patogenesis infeksi Salmonella typhi dapat berlangsung selama 1 - 3 minggu dan melibatkan sistem imun innate dan adaptive host. Pemeriksaan laboratorium yang menjadi pilihan meliputi pemeriksaan kultur sebagai gold standard, pemeriksaan penunjang yang dapat mendukung diagnose demam tifoid adalah pemeriksaan serologis, pemeriksaan molekuler seperti PCR, dan POCT. Gambaran hematologis dari demam tifoid paling umum adalah ditemukan leukositosis dan eosinopenia, dengan hasil pengukuran kadar enzim AST dan ALT meningkat 2-3 kali dari nilai normal.

\section{UCAPAN TERIMA KASIH}

Ucapan terima kasih kepada seluruh pihak terkait yang telah membantu dan bekerjasama dalam penyelesian literature review ini.

\section{REFERENCES}

Andualem, G. et al., 2014. A Comparative study of widal test blood culture in the diagnosis of typhoid fever in febrile patients. BMC Research Note, Issue 7, p. 653.

Baker, S., Favorov, M. \& Dougan, G., 2010. Searching for the elusive typhoid diagnostic. BMC Infect Dis, I(10).

Chart, H. et al., 2007. Serodiagnosis of salmonella enterica serovar typhi and serovar paratyphi A,B and C human infections. J Med Microbiol, Issue 56, pp. 1161 -1166.

Choerunnisa, T. \& Basuki, 2014. Proporsi pemeriksaan IgM anti salmonella typhi 09 positif menggunakan tubex dengan pemeriksaan widal positif pada pasien klinis demam tifoid akut di RSUD Dr. H. Abdoel Moeloek Bandar Lampung. Medical Journal of Lampung University, 3(1), pp. 102 - 110.

Crump, J., Sjolund-KArlsson, M., Gordon, M. \& Parry, C., 2015. Epidemiology, clinical presentation, laboratory diagnosis, antimicrobial resistence, and antimicrobial management of invasive Salmonella infections. Clin Microbiol Rev, 28(5). 
Gordon, M. et al., 2010. Invasive non-typhoidal salmonellae establish systemic intraceluler infection in HIV ifected adults an emerging disease pathogenesis. Clin Infect Dis, Issue 50, pp. 953-962.

House, D. et al., 2001. Typhoid fever: pathogenesis and disease. Curr Opin Infect, Issue 14, pp. 573 - 578.

Kaur, J. \& Jain, S., 2012. Role of antigens and virulence factors od salmonella enterica serovar typhi in its pathogenesis. Microbiological research, 1(1), pp. 199-210.

Kumar, A. et al., 2010. Quick PCR based diagnosis of typhoid using spesific genetic markers. Biotechnol Lett, Issue 53, pp. 707 - 712.

Kumar, G. et al., 2012. Use of urine with nested PCR targeting the flagellin gene (fliC) for diagnosis of typhoid fever. J Clin Microbiol, Issue 50, pp. 1964 - 1967.

Lestari, A. A. W., Sukrama, I. D. M. \& Nurmansyah, D., 2019. The earthworm (Lumbricus rubellus) extract decreased amino transaminase enzyme level and number of bacterial colony in male wistar rate infected with Salmonella typhimurium. Biomedical \& Pharmacology Journal, 12(1), pp. 325 - 332.

Ley, B. et al., 2010. Evaluation of widal tube aglutination test for the diagnosis of typhoid fever among children admitted to a rural hospital in Tanzania and a comparison with previous studies. BMC Infect Dis, Issue 10, p. 180.

Liu, Y. et al., 2017. Comprehensive analysis reveals two distinct evolution patterns of salmonella flagelin gene cluster. Frontiers in Microbiology, 8(2604).

Lozano, R. et al., 2010. Global and regional mortality frm 235 causes of death for 20 age groups in 1990 and 2010 : asystematic analysis for The Globa Burden of Disease study. Lancet, Issue 380, pp. 2095 - 1228.

Marleni, M., Iriani, Y., Tjuandra, W. \& Theodorus, 2014. Ketepatan uji TubexTF dalam mendiagnosis demam tifoid anak pada demam hari ke-4. Jurnal Kedokteran dan Kesehatan, 1(1), pp. $7-11$.

Mogasale, V. et al., 2014. Burden of typhoid fever in low income and middle come countries: a systematic, literature-based update with risk factor adjusment. Lancet Glob Health, Issue 2, pp. 570 - 580 .

Moore, C. et al., 2014. Evaluation of the diagnostic accuracy of a typhoid IgM flow assay for the diagnostic of typhoid fever in Cambodian children using a Bayesian latent class model assuming an imperfect gold standard. Am J trop Med Hyg, Issue 90, pp. 114 120.

Muchtarommah, B., 2014. pengauh Dosis dan lama pemberian tepung cacing tanah terhadap kadar enzim SGPT dan SGOT tikus yang terinfeksi Salmonella typhi. National Conference Green Technology, Issue 3, pp. 345 - 350.

Nelwan, R., 2012. Tata Laksana Terkini Demam Tifoid. Continuin Medical Education : CDK, 39(4). 
Nga, T. et al., 2010. The sensitivity of real time PCR amplification targeting invasive Salmonella serovars in biological specimens. BMC Infect Dis, Issue 10, p. 125.

Parry, C. et al., 2002. Typhoid Fever. N Engl J Med, Issue 347, pp. 1770 - 1782.

Pulickal, A. et al., 2009. Kinetics of the natural, humoral immune response to Salmonella enterica serovar typhi in Kathmandu,Nepal. Clin Vaccine Immunol, Issue 16, pp. 1413-1419.

Septiawan, I. \& S Herawati, I. Y., 2013. Pemeriksaan Immunoglobulin M anti Salmonella dalam diagnosis demam tifoid. E-Jurnal Medika Udayana, 2(6), pp. 1080 - 1090.

Sheikh, A., 2011. In vivo expression of Salmonella enterica serotype typhi genes in the blood of patients with typhoid fever in Bangladesh. PNTD, 5(12).

Siba, V. et al., 2012. Evaluation of serological diagnostic test for typhoid fever in Papua New Guinea using composite reference standard. Clin Vaccine Immunol, Issue 19, pp. $1833-1837$.

Sidabutar, S. \& Satari, H., 2010. Pilihan Terapi empiris Demam Tifoid pada Anak: Kloramfenikol atau Seftriakson?. Sari Pediatri, Issue 11, pp. 434-439.

Singh, S., 2001. Symposium: Typhoid fever pathogenesis and laboratory diagnosis. J Indian Academy of Clinical Medicine, II(1).

Sucipta, A., 2015. Baku emas pemeriksaan laboratorium demam tifoid pada anak. Jurnal Skala Husada, 1(12), pp. 22 - 26.

Tam, F. et al., 2008. New rapid test dor paratyphoid a fever : usefulness, cross-detection, and solutin. Diagn Microbiol Infect Dis, Issue 62, pp. 142 - 150.

Tarupiwa, A. et al., 2015. Evaluation of Tubex TF and Onsite Typhoid IgG/IgM Combo rapid test to detect Salmonella enterica serovar typhi infection during a typhoid outbreaks in Harare, Zimbabwe. BMC Res Notes, Issue 8, p. 50.

Tortora, G., Berdell, R. \& Case, C., 2013. Microbiology: an Introduction. 11th ed. s.1.:Pearson.

Waddington, C. et al., 2014. An outpatient, ambulant-design, controlled human infection model using escalating doses of Salmonella Typhi challenge delivered in sodium bicarbonate solution. Clin Infect Dis, Issue 347, pp. 1770 - 1782. 